\title{
Hannah Arendt e o totalitarismo como forma de governo apoiada na ralé e nas massas
}

\author{
Hannah Arendt and the totalitarianism as a form of government \\ based on the mob and the masses
}

Felipe Augusto Mariano Pires ${ }^{1}$

\begin{abstract}
1 Mestre em Filosofia pela UFPE. Graduação em Filosofia pela UFPE. Professor Assistente da Universidade Federal Rural do Semi-Árido, Brasil. E-mail: nitrorhiso@hotmail.com
\end{abstract}

RESUMO: Em Origens do Totalitarismo, Hannah Arendt faz uma caracterização do totalitarismo como uma forma de governo inédita, fincada em duas novas camadas sociais, a ralé e as massas. Sua descrição do totalitarismo é realizada a partir de uma diferenciação com a tirania. Este trabalho buscou observar como o surgimento dos supracitados grupos sociais permitiram o surgimento dessa nova forma de governo. Vimos que a definição dela de povo diferencia-se da tradicional, quando afirma ser o povo diretamente relacionado à busca de um sistema verdadeiramente representativo. Esta diferenciação é realizada em relação a dois grupos sociais, a ralé, que é composta do refugo da sociedade capitalista, dos declassés, daqueles que não encontram representação no sistema político, e que é também subproduto da burguesia, não se desligando desta, e as massas, que são formadas pelas pessoas desarticuladas e isoladas, neutras, indiferentes politicamente, atomizadas, supérfluas, resultantes de um mundo destruído. Para a autora, o totalitarismo emerge quando líderes da ralé passam a ser a força motriz das massas. O totalitarismo é mostrado como o criador de um simulacro da realidade, que aproveitou-se do esvaziamento do espaço público, começando a diferenciar-se da tirania pelo terror pós-eliminação da oposição, pelo líder ser parte da engrenagem e instrumento de desresponsabilização, por não se separar da propaganda, por seu amorfismo e pelo fato do campo de concentração ser o espelho e a miniatura da sociedade almejada.

Palavras-chave: Hannah Arendt. Formas de Governo. Totalitarismo.

ABSTRACT: In Origins of Totalitarianism, Hannah Arendt makes a characterization of totalitarianism as an unprecedent form of government, rooted in two new social strata, the mob and the masses. Her description of totalitarianism is made from a differentiation with tyranny. This work sought to observe how the the emergence of the aforementioned social groups allowed the emergence of this new form of government. We have seen that her definition of people is different from the traditional one, when she claims that the people is directly related to the search for a truly representative system. This differentiation is made in relation to two social groups, the mob, which is composed of de capitalist society's reject, the declassés, those who find no representation in the political system, and who is also burgeoisie's byproduct, never disconnecting with it, and the masses, which are formed by disjointed and isolated, neutral, politically indifferent, atomized, superfluous people, resulting from a destroyed world. For the author, totalitarisnism emerges when leaders of the mob become the driving forces of the masses. Totalitarianism is shown as the creator of a simulacrum of reality, which took advantage of the public space's emptying, beginning to diferentiate itself from tyranny by the terror after oposition's elimination, by its leader being part of the mechanism and lack of responsability's instrument, for not being separated from propaganda, by its amorphism and by the fact that the concentration camp is the mirror and the miniature of the desired society.

Keywords: Hannah Arendt. Forms of government. Totalitarisnism. 


\section{Introdução}

Hannah Arendt não tinha um grande interesse em política até a ascensão do fascismo na Alemanha e a queima do Reichstag, o parlamento alemão, em 1933, momento no qual decidiu que não mais podia continuar sendo uma mera espectadora. Segundo a filósofa, o fenômeno do totalitarismo deixou clara a fragilidade da esfera da ação pública. Para Arendt, o espaço público encontrava-se arriscado a uma perda definitiva, caso não fosse sustentado por uma participação ativa. A despolitização da sociedade moderna tinha detixado o mundo vulnerável ao que ela chamou "antipolítica do totalitarismo" (BUCKLER, 2011).

Morgenthau (1977) esclarece o que Arendt entende por política, do seguinte modo:

O que nós consideramos como ação política é para ela os passos preparatórios em direção à verdadeira ação política, ou de outro modo eles são irrelevantes à verdadeira ação política. O verdadeiro ato político é um ato de liberdade, um ato realizado por indivíduos livres na arena pública, indivíduos livres que interagem uns com os outros, e que expressam suas preferências pessoais através deste interação. Isto e apenas isto é política (p. 128; tradução nossa).

O supracitado início de interesse e participação deu origem ao livro Origens do Totalitarismo (ARENDT, 1998), no qual, além de, como o próprio título já indica, tecer uma análise acerca do contexto e dos acontecimentos que deram origem ao totalitarismo, a autora alemã faz uma caracterização deste como forma de governo, concluindo que se trata de um tipo completamente inédito, fincado em duas camadas sociais também absolutamente novas, a saber, a ralé e as massas. Buckler (2011) leciona que o texto mistura um relato histórico das origens do totalitarismo, uma análise das suas principais características e quais os dilemas que tal acontecimento levantaram ao mundo.

Wolin (1983) explica que a interpretação da guerra do ponto de vista das pessoas comuns, gerada a partir dos jornais, das revistas, do rádio e do cinema, era de uma disputa entre a democracia e a ditadura. Havia a difundida asseveração de que o forma de chegar à natureza do totalitarismo era através de uma antítese com a democracia: liberdade de expressão de um lado, educação para controle do pensamento e manipulação das massas de outro, sistema democrático de partidos políticos livres de um lado, apenas um partido que usava o terror e a intimidação de outro.

Villa (2006) salienta que Arendt nunca escreveu uma filosofia política aos moldes sistemáticos e que seus textos não seguem uma narrativa linear, baseando-se, ao invés disso, em uma série de distinções conceituais, como, a título de exemplo, a distinção entre tirania e totalitarismo.

Correia (2006) nos recorda que a tese de Arendt do totalitarismo como forma de governo nunca antes existente foi inspirada em Carlton Hayes, que, no primeiro colóquio universitário dedicado ao totalitarismo, realizado na Filadélfia em 1939, fez tal afirmação de ineditismo, adicionando ainda a alegação de que os líderes totalitários vinham da plebe e se sustentavam nas massas, que eram mobilizadas e coordenadas através do terror e da propaganda. Para Hayes, o fato de os líderes não virem da aristocracia, mas da plebe, fez com que os mesmos fossem ouvidos pelas massas.

Para entendermos melhor esta questão, na história da teoria das formas de governo, a formulação que ganhou o status de clássica é aquela realizada por Aristóteles na Política (2009) - e que também aparece na Ética a Nicômaco (1985), mas de um modo menos completo. Na catalogação do Estagirita, baseada no número de governantes, aparecem seis formas de governo, três boas e três más: monarquia, aristocracia e politeia - as boas - e tirania, oligarquia e democracia - as más. O que separaria as boas das degeneradas seria a presença ou não da virtude (aretê) nos governantes. Das seis formas, a mais nociva seria a tirania, 
que une o máximo poder com a máxima ausência de virtude. Além disso, a referida tipologia baseia-se em três classes das quais a própria sociedade seria formada: os monarcas, os aristocratas e o povo.

A grande maioria das teorias das formas de governos dos filósofos posteriores, mesmo que trazendo consigo suas variações, adotam esse modelo de seis formas. Portanto, o livro de Hannah Arendt adquire um especial interesse quando afirma ter surgido uma inédita forma de governo, ainda mais nociva do que a tirania, alicerçada em dois estratos sociais inteiramente novos. Somando-se a isso, o totalitarismo é, provavelmente, o maior fantasma que herdamos do século XX.

Como, após dois ou três séculos de sonhos democráticos, de defesa de um mundo de liberdade, igualdade e fraternidade, a humanidade embarcou em um trem fantasmagórico, viajando em direção à autodestruição? Villa coloca uma questão muito semelhante: "Como é que a Europa, berço do Iluminismo e dos Direitos do Homem, deu à luz uma forma de política tão brutalmente assassina como o totalitarismo" (VILLA, 2006, p. 3; tradução nossa).

O objetivo deste trabalho, portanto, é observar como, no pensamento de Hannah Arendt, o surgimento histórico de dois novos grupos sociais, diferenciando o povo, a ralé e a massa permitiu o surgimento de uma nova forma de governo, o totalitarismo e o que é que caracteriza esta nova forma de governo para Hannah Arendt, especialmente em Origens do Totalitarismo (ARENDT, 1998).

\section{0 povo, a ralé e as massas}

Trata-se de um ponto em comum da teoria das formas de governo a identificação das classes da sociedade como os monarcas, os aristocratas e o povo. O demos, a plebe, formado por agricultores, artesãos e trabalhadores braçais de toda sorte, seria justamente aquela camada da polis maior em número, mas incapaz de obter a virtude, seja por sua própria natureza inferior, seja pela falta de tempo para dedicar-se a tão elevado objetivo (cf. PLATÃO, 1965; ARISTÓTELES, 2009). A questão é que o citado demos, não importa qual seja a sua relação com a polis, é indiferenciado. Aliás, já devido à suprarreferida ausência de virtude, não se esperaria espontaneamente dessa classe atos considerados bons, e sim que os governantes os forçassem a agir de acordo com o bem.

$\mathrm{Na}$ modernidade, que se insurge contra as monarquias hereditárias e, de certo modo, contra as aristocracias, é que se passa a ver o povo com outros olhos e a esperar algo positivo do mesmo, na forma de sua vontade, à qual os direcionamentos do governo deveriam espelhar. A virtude dá lugar à vontade, mais especificamente à vontade do povo, essa camada populacional mais numerosa e considerada a mais grosseira, como aquilo que deve dirigir o governo ao bem comum. Todavia, o povo na modernidade permanece uma classe indiferenciada.

Hannah Arendt (1998), por sua vez, possui um novo conceito de povo. Para a filósofa, o povo é um grupo formado por todas as classes sociais, diferenciando-se, portanto, da plebe, e que, em todas as suas revoluções, luta por um sistema verdadeiramente representativo. Povo é aquele conjunto populacional que busca possuir (ou acredita possuir, ou de fato possui) uma representação no governo dentro de um sistema representativo. Como bem salienta Correia (2006), o povo em Arendt é aquele grupo que, em suas revoluções e pressões por reformas, visa um sistema de fato representativo, busca fazer-se representar no parlamento.

Por trás dessa definição de povo está o fato de que o sistema político moderno implementado, e que ainda nos dias atuais chamamos "democracia", foi uma forma de governo mista, aos moldes do que podemos encontrar em Locke (2001), ainda de uma forma seminal, mas principalmente em Montesquieu 
(1979) e no Federalista, de Madison, Hamilton e Jay (1973), forma esta que forneceria uma representatividade para as três classes sociais, o princípio monárquico representado pelo chefe do executivo e um parlamento bicameral, com um grupo de característica aristocrática e outro de representantes do povo.

Em Hannah Arendt (1998), portanto, o "povo" seria formado por indivíduos das três classes tradicionais anteriormente citadas, do mesmo modo que os dois outros grupos citados nas Origens do Totalitarismo, a ralé e as massas. Para Arendt, é um grande erro não diferenciar povo e ralé, pois a ralé é uma caricatura do povo. Arendt conceitua a ralé (mob) como os "declassés provenientes de todas as camadas" (ARENDT, 1998, p. 30).

Em suas próprias palavras:

A ralé é fundamentalmente um grupo no qual são representados resíduos de todas as classes. É isso que torna tão fácil confundir a ralé com o povo, o qual também compreende todas as camadas sociais. Enquanto o povo, em todas as grandes revoluções, luta por um sistema realmente representativo, a ralé brada pelo "homem forte", pelo "grande líder". Porque a ralé odeia a sociedade da qual é excluída, e odeia o Parlamento onde não é representada (ARENDT, 1998 p. 129).

Em suma, a ralé é aquele grupo excluído da sociedade, que não encontra representatividade no sistema político e não busca tal representatividade. Pelo contrário, a ralé despreza o parlamento e a própria sociedade, apresentando como uma de suas principais característica uma grande volubilidade. Para Arendt, o ódio ao parlamento faz com que os políticos que se apoiam na ralé utilizem o plebiscito como tática. O próprio modus operandi da ralé é através da via extraparlamentar e este refugo do capitalismo possui uma inclinação a enxergar as forças políticas através de conspirações:

Excluída, como é, da sociedade e da representação política, a ralé recorre necessariamente à ação extraparlamentar. Além disso, sente a inclinação de procurar as verdadeiras forças da vida política naqueles movimentos e influências que os olhos não vêem e que atuam por detrás das cortinas (ARENDT, 1998 p. 130).

A filósofa alemã enfatiza uma vinculação perene entre a ralé e as classes superiores: "As classes superiores sabiam que a ralé era a carne da sua própria carne, e o sangue do seu próprio sangue" (ARENDT, 1998, p. 130). A ralé encontra-se em uma natural aliança com a burguesia. Uma melhor explicação dessa afirmação está no tópico intitulado A Aliança entre a Ralé e o Capital, no qual Arendt oferece uma explicação histórica.

O imperialismo (anos 80 do século XIX) surgiu para dar conta de estruturas políticas obsoletas. Havia na Europa uma produção excessiva de capital, um excesso de dinheiro guardado, derivado da produção capitalista em um sistema em que havia uma má distribuição, que estava além da capacidade de produção e consumo, era um dinheiro supérfluo. A questão é que os capitalistas haviam percebido, através das crises e depressões pelas quais haviam passado, que o seu sistema econômico de produção dependia da oferta e da procura, mas que, naquele ponto, o mercado doméstico estava saturado, com falta de matériasprimas e constantes crises. A solução encontrada foi a exportação deste capital.

Contudo, Arendt afirma que a produção capitalista tinha dois subprodutos: o capital supérfluo e o que ela chamou de "lixo humano", a ralé (ARENDT, 1998, p. 180). A cada crise, que se seguia sempre a um período de crescimento industrial, um contingente de pessoas era eliminado da sociedade produtiva e tornado ocioso. Logo, junto com a exportação do capital, o "lixo humano" passou a também ser exportado, ajudando a povoar o Canadá, a Austrália e os E.U.A. Iniciou-se, então, um período de expansão ilimi- 
tada, no qual os “donos do capital supérfluo" usavam os homens supérfluos (ARENDT, 1998, p. 180).

Segundo a filósofa, o surgimento e crescimento da ralé foi notado já pelos grandes historiadores do século XIX, como Burckhardt e Spengler, mas que o que estes não haviam percebido é que este grupo não podia ser identificado nem com o crescimento da classe trabalhista industrial nem com o povo como um todo, pois a ralé era composta "do refugo de todas as classes" (ARENDT, 1998, p. 185). Pelo fato de provir de todas as classes, a ralé parecia ter abolido as diferenças de classe e assemelhava-se ao próprio povo, todavia, segundo Arendt, o supramencionado refugo populacional nada mais era do que a "distorção e caricatura" do povo (ARENDT, 1998, p. 185), que trazia consigo uma "irresponsabilidade fundamental" (ARENDT, 1998, p. 185) e o perigo de transformação da democracia em um despotismo, com tiranos surgindo da ralé e mantendo-se pelo seu apoio.

Para a pensadora alemã, o que tais historiadores não compreenderam é que a ralé não é só o refugo, mas também o subproduto da sociedade burguesa, gerado por ela e sempre ligado a ela. Não devemos esquecer a seguinte passagem: "As classes superiores sabiam que a ralé era a carne da sua própria carne, e o sangue do seu próprio sangue" (ARENDT, 1998, p. 130). E o que passou a se suceder foi uma admiração da alta sociedade pelo submundo, fato que só provaria o parentesco ideológico entre os dois grupos.

Hannah Arendt (1998) define as massas como pessoas que não se unem por interesse comum e que não possuem a articulação de classes, que resultaria em objetivos determinados. São, pelo contrário, pessoas neutras ou indiferentes politicamente, que não podem se integrar em uma organização fundada no interesse comum, como os partidos, os sindicatos e as organizações profissionais, e que raramente exercem o direito de votar. Sobre a diferença das massas em relação à ralé, a autora afirma:

A relação entre a sociedade de classes dominada pela burguesia e as massas que emergiram do seu colapso não é a mesma entre a burguesia e a ralé, que era um subproduto da produção capitalista. As massas têm em comum com a ralé apenas uma característica, ou seja, ambas estão fora de qualquer ramificação social e representação política normal. As massas não herdam, como o faz a ralé, os padrões e atitudes da classe dominante, mas refletem, e de certo modo pervertem, os padrões e atitudes de todas as classes em relação aos negócios públicos. Os padrões do homem da massa são determinados não apenas pela classe específica à qual antes pertenceu, mas acima de tudo por influências e convicções gerais que são tácitas e silenciosamente compartilhadas por todas as classes da sociedade (ARENDT, 1998, p. 364).

Segundo Arendt, no início do século XIX, os homens de letras e estadistas já previam o surgimento do homem da massa e a chegada de uma era da massa. Contudo, de modo contrário ao que estes haviam previsto, as massas não foram fruto da igualdade de condições e da expansão da educação, o que levaria a uma queda na qualidade e a um conteúdo mais popularizado. Segundo a filósofa, até pessoas cultas passaram a ser atraídas pelos movimentos de massa, abandonando-se na massa. "A atomização social e a individualização extrema precederam os movimentos de massa” (ARENDT, 1998, p. 366). Estes, em vez de atraírem os membros típicos dos partidos, atraíram "os completamente desorganizados, os típicos 'não alinhados' que, por motivos individualistas, sempre se haviam recusado a reconhecer laços ou obrigações sociais" (ARENDT, 1998, p. 366).

"A verdade é que as massas surgiram dos fragmentos da sociedade atomizada" (ARENDT, 1998, p. 366), uma sociedade que possui uma estrutura competitiva associada a uma grande solidão do indivíduo. "A principal característica do homem da massa não é a brutalidade nem a rudeza, mas o seu isolamento e a sua falta de relações sociais normais" (ARENDT, 1998, p. 367), afirma a filósofa.

Segundo Arendt, essas massas provieram da sociedade do Estado-nação, uma sociedade de classes 
unidas pelo viés de um sentimento nacionalista, e aderiram a um nacionalismo violento no "primeiro desamparo da sua existência" (ARENDT, 1998, p. 367).

Canovan (2006) assim explica a definição de Arendt de massas:

Arendt sustenta que a maioria dos recrutas dos movimentos totalitários pertenciam às "massas": pessoas desenraizadas, desorientadas, que já não tinham mais um claro sentido de realidade ou autointeresse porque o mundo que elas haviam habitado havia sido destruído pelas perturbações do desemprego, da inflação, da guerra e da revolução. Mas sua condição era apenas uma faceta de uma mais difundida experiência de "superfluidade" (p. 31; tradução nossa).

As massas eram formadas por pessoas desamparadas, passivas, "supérfluas", sem lugar definido no mundo, enfim, as vítimas ideais, perfeitas para se associar aos movimentos totalitaristas, que eram movimentos de massa.

\section{0 totalitarismo como nova forma de governo, a eliminação da oposição e o líder}

Tendo a sociedade moderna, portanto, originado estes dois novos grupos, estava delineado o contexto da ascensão de uma nova forma de governo, mais terrível do que a pior das tiranias que já existiu no passado. Para Arendt (1998), o totalitarismo é essencialmente diferente da tirania, do despotismo e da ditadura. Ele transforma classes em massas, o sistema partidário em um movimento de massa, transfere o centro do poder do exército para a polícia e visa ao domínio mundial.

De acordo com a filósofa, os governos totalitários contavam com o (e se baseavam no) apoio das massas. Segundo a autora, embora houvesse a negação de muitos especialistas, que viam o totalitarismo como um resultado da força da máquina de propaganda e da lavagem cerebral, a população alemã em 1939-1940 sabia o que estava acontecendo com os judeus e sobre a preparação do ataque à Rússia, sem que isso arrefecesse o seu apoio.

Como existem várias características comuns entre os governos totalitários e as tiranias, a primeira tentação é realizar a imediata catalogação do totalitarismo na categoria da tirania. Todavia, para Arendt, "o totalitarismo nos coloca diante de uma espécie totalmente nova de governo" (ARENDT, 1998, p. 513) e o seu o trabalho, na contracorrente de realizar uma teoria completa das formas de governo, assume a teoria clássica e se concentra em fazer a distinção entre tirania e totalitarismo, como nos mostra a seguinte passagem:

as formas de governo sob as quais os homens vivem são muito poucas; foram descobertas cedo, classificadas pelos gregos, e demonstraram rara longevidade. Se aplicarmos esses dados, cuja ideia fundamental, a despeito de muitas variações, não mudou muito nos dois milênios e meio que vão de Platão a Kant, somos imediatamente tentados a interpretar o totalitarismo como forma moderna de tirania, ou seja, um governo sem leis no qual o poder é exercido por um só homem (ARENDT, 1998, p. 513).

Segundo Canovan (2006), a própria Arendt, posteriormente às Origens do Totalitarismo, afirmou que estava seguindo os passos de Montesquieu (1979), dando um relato generalizado de uma nova forma de governo a ser adicionada à tipologia do filósofo em questão, seguindo os mesmos passos de analisar a "natureza" de cada forma e o seu "princípio". Em nossa opinião, Arendt não procede de uma maneira tão metódica quanto Montesquieu (1979), ao menos não na exposição das ideias.

Para Arendt (1998), o totalitarismo desafia as leis positivas, mas não deixa de operar segundo uma 
lei, que seria a própria fonte das leis, as da Natureza e da História. Ele diz recorrer à própria fonte de autoridade das leis. Não há a substituição de um conjunto de leis por outro, mas a criação de uma nova forma de legalidade.

A ascensão do totalitarismo alterou definitivamente o modo como se enxergava a democracia. De acordo com a autora, tinha-se a ilusão de que a maioria do povo participava ativamente do processo político e de que a maioria dos indivíduos simpatizava com algum partido, e não que uma massa politicamente neutra podia facilmente ser a maioria das pessoas de um país e, além disso, assumir um papel de protagonismo político.

Quando os movimentos totalitários invadiram o parlamento, conseguiram colocar em cheque a confiança na própria ideia de que a democracia era um governo baseado na maioria. A afirmação de que os movimentos totalitários utilizam-se das liberdades democráticas para suprimi-las repousa no fato de que essas liberdades só possuem significado quando os cidadãos participam de alguma forma do sistema de representação.

Contudo, segundo a autora, a questão vai mais além. A neutralidade e a indiferença em relação aos negócios públicos não seriam, por si mesmas, as causas dos movimentos totalitários, e sim a sociedade competitiva de consumo, criada pela burguesia, que gerou apatia e hostilidade a respeito das questões públicas. E esta hostilidade não foi exclusiva das camadas sociais exploradas, mas da própria burguesia. Com o advento do imperialismo, a burguesia tornou-se muito hostil às instituições existentes e buscou exercer o poder político. Dentro da mentalidade burguesa, o supremo objetivo do indivíduo era o sucesso dentro de uma acirrada competição. Os deveres do cidadão eram, logo, vistos como perda de tempo. Esta mentalidade favorece as formas de ditadura baseadas em um "homem forte". Ainda assim, a mentalidade burguesa ainda é contrária ao totalitarismo, pelo seu caráter individualista.

Os movimentos totalitários nascem como antiburgueses, no direcionamento mesmo de apagar a identidade do indivíduo e integrá-los no todo. O totalitarismo tem seu início quando as massas passam a apoiar espontaneamente os novos líderes da ralé, que, por sua vez, passa a ser a força motriz das massas, deixando de ser agente da burguesia. Os líderes da massa, como Hitler e Stálin, segundo Arendt, vieram da ralé. Stálin de uma parte conspirativa, formada por proscritos e revolucionários, do Partido Comunista da U.R.S.S. e Hitler de um partido composto por "desajustados, fracassados e aventureiros, [...] 'um exército de boêmios' [...] o avesso da sociedade burguesa” (ARENDT, 1998, p. 367).

A distinção entre tirania e totalitarismo começa, para Arendt (1998), no fato de que a tirania exerce a sua violência, mesmo que ininterrupta, contra a camada de opositores do governo presente na sociedade, enquanto que o totalitarismo consegue eliminar toda a oposição e, ainda assim, continua exercendo o terror. Aliás, é nesse momento em que o totalitarismo intensifica e sofistica o seu terror. Para Arendt, aquilo que mais caracteriza o terror totalitário é desencadeado "quando toda a oposição organizada já desapareceu e quando o governo totalitário sabe que já não precisa ter medo” (ARENDT, 1998, p. 345).

O totalitarismo tem como objetivo, e de fato consegue, organizar as massas, diferentemente dos partidos, que visavam organizar as classes ou cidadãos com opiniões peculiares sobre a condução dos negócios públicos. A força numérica dos movimentos totalitários também é bem diferente daquela dos grupos políticos. Estes dependem de uma força numérica, mas o totalitarismo depende da força bruta, parecendo, aos olhos da autora, impossível em países com pouca população. Em países menores, os movimentos totalitários deram origem a ditaduras não-totalitárias, de classe ou de partido, mas não a um totalitarismo propriamente dito. Para o domínio total, segundo Arendt, seria preciso um material humano numeroso o suficiente para suportar a perda populacional que requer a implementação deste domínio, que é uma 
“máquina de poder e da destruição de homens” (ARENDT, 1998, p. 361). Nas palavras da filósofa, "Somente onde há grandes massas supérfluas que podem ser sacrificadas sem resultados desastrosos de despovoamento é que se torna viável o governo totalitário" (ARENDT, 1998, p. 361).

A tirania, na teoria das formas de governo mais clássica, que é a de Aristóteles (2009), é mostrada como o governo vicioso de um só. O totalitarismo possui como semelhança à tirania a figura de um governante único, mas no totalitarismo o líder é a própria representação personificada daquele sistema.

Existe o que consideramos ser uma contradição apenas aparente no trabalho de Arendt (1998) em relação à questão de o líder ser ou não substituível. Em um determinado momento do livro (cf. p 355 e seguintes), a autora afirma que há uma facilidade de substituição dos líderes totalitários. Esta seria uma diferença importante em relação à tirania. Segundo ela, Stálin foi substituído sem concessões à sua memória e Hitler, depois de morto, encontra-se esquecido e representa muito pouco inclusive entre grupos neonazistas e neofascistas da Alemanha. Para a autora, isso se liga à volubilidade das massas, mas deriva principalmente da essência do totalitarismo, que, para ela, apenas se mantém no poder estando em movimento e dando movimento a tudo o que se encontra em volta, é uma grande adaptabilidade e falta de continuidade.

Em um outro ponto, a partir da página 424, a pensadora afirma que o líder, estando no centro do movimento totalitário, passa a ser insubstituível. Ele se encontra separado da elite deste movimento por um círculo interno de iniciados "que o envolvem numa aura de impenetrável mistério correspondente à sua 'preponderância inatingível”' (ARENDT, 1998, p. 423). Ali, ele demonstra uma extrema capacidade em armar intrigas entre os membros e realiza trocas frequentes de pessoal, além de manipular as lutas internas do partido pelo poder. Ele não usa da violência da mesma forma que o ditador. Não precisa das organizações paramilitares para manter-se na posição de líder. A autora afirma: "toda a hierarquia partidária está eficazmente treinada para o único fim de transmitir rapidamente o desejo do Líder a todos os escalões. A essa altura, o Líder torna-se insubstituível, porque toda a complicada estrutura do movimento perderia a sua raison d'être sem as suas ordens" (ARENDT, 1998, p. 424).

O líder se mantém pela convicção do seu círculo mais próximo de que, sem ele, todo o movimento ruiria. É a própria personificação do muro que separa o movimento do mundo real, é a defesa e a ponte entre o movimento e este mundo. Assume a responsabilidade pessoal e total por tudo o que é feito, tornando cada funcionário a sua encarnação viva e fazendo parecer que toda ordem emana dele, criando a imagem de que ninguém precisa assumir a responsabilidade pelos seus próprios atos. Isso é uma diferença sua com o mero tirano, que não se responsabiliza por seus subordinados, mas, antes, usa-os como bodes expiatórios.

Interpretamos essa aparente contradição da seguinte forma: A imagem do líder totalitário, diferentemente do tirano, que impõe o seu jugo a uma população, é a de um comandante. Na teoria das formas de governo tradicional, aqueles que governavam em uma forma de governo boa, possuíam a virtude e sabiam o caminho que toda a polis deveria tomar para o bem. Pelas leis, a própria polis assumia a forma do bem e era capaz de conduzir todas as classes, inclusive o demos, a agir de acordo com o bem. Já o totalitarismo consegue fazer uma caricatura disso, mas o resultado é completamente inverso. Quando há um simples tirano, está claro que ele é um tirano, já o líder totalitário finge ser uma espécie de monarca virtuoso. Segundo Hannah Arendt, os regimes totalitários e seus líderes "sempre 'comandam e baseiam-se no apoio das massas" (ARENDT, 1998, p. 356). Eles organizam e comandam as massas, dando a impressão de governantes virtuosos, mas o que acontece é um processo no qual aquele que comanda depende da massa de comandados ao mesmo tempo em os devora. Na tirania, o sistema é estabelecido em função do líder, 
para mantê-lo no poder, já no totalitarismo, o líder é parte do sistema, sendo, na realidade, perfeitamente substituível, mas dando a impressão contrária, pois todo o sistema é realizado "em nome do líder", para "fazer realidade as ordens do líder". Na verdade, no totalitarismo, a figura do líder é um instrumento de desresponsabilização. Agindo para fazer a vontade do líder, ninguém é responsável por seus atos. O sistema tem como finalidade a sua própria implantação e manutenção, mas aparentando agir de acordo com as visões do líder. Em nossa opinião, é nesse sentido que Arendt afirma que o líder passa a ser insubstituível, no sentido de que o totalitarismo simplesmente precisa da figura de um líder e das suas ordens para a sua própria existência e manutenção, mas, como se trata de um sistema baseado na imagem, o que é insubstituível é a imagem, e não a pessoa. Precisa existir um líder, não importa quem seja, pois a imagem não condiz com a pessoa.

Para Arendt,

o líder totalitário é nada mais e nada menos que o funcionário das massas que dirige; não é um indivíduo sedento de poder impondo aos seus governados uma vontade tirânica e arbitrária. Como simples funcionário, pode ser substituído a qualquer momento e depende tanto do 'desejo' das massas que ele incorpora, como as massas dependem dele. Sem ele, elas não teriam representação externa e não passaria de um bando amorfo; sem as massas, o líder seria uma nulidade (ARENDT, 1998, p. 375).

É, portanto, uma relação simbiótica entre o líder e as massas. Toda a organização se identifica com o líder de modo absoluto, de modo que ele é considerado infalível. O líder aparenta guiar o movimento sempre na direção certa. O que caracteriza a lealdade do séquito do líder, nas palavras de Arendt, "não é a crença na infalibilidade do Líder, mas a convicção de que pode tornar-se infalível qualquer pessoa que comande os instrumentos de violência com os métodos superiores da organização totalitária" (ARENDT, 1998, p. 438).

\section{A propaganda, o terror e a atomização}

Hannah Arendt (1998) reconhece a importância da propaganda para o sistema totalitário, mas não enxerga a propaganda como o sustentáculo de tudo, como, segundo ela mesma, muitos estudiosos o fizeram. A propaganda não era a grande culpada, apesar do totalitarismo não se separar da propaganda. Para Arendt, a popularidade tanto de Hitler quanto de Stálin não pode ser simplesmente atribuída a uma "propaganda magistral e mentirosa que conseguiu arrolar a ignorância e a estupidez" (ARENDT, 1998, p. 356). Entendemos que o que ela apontava e enfatizava era o contexto propício no qual tudo surgiu: a formação da ralé e das massas, com a decadência do espaço público e o consequente isolamento desses indivíduos no âmbito privado.

A propaganda totalitária, de acordo com a autora, é, ao mesmo tempo, franca e mentirosa, valoriza o mal e tem um desprezo pelos padrões morais comuns. Em nosso entendimento do pensamento de Arendt, a questão é que, não é que a propaganda fosse algo magistral, uma espécie de chamado irresistível que hipnotizou e arrastou toda uma população a cometer o que foi cometido, ela mostra um ineditismo ao dirigir-se diretamente a um contingente de pessoas cuja importância havia sido ignorada e que estava isolado tanto do âmbito das decisões políticas quanto dos próprios laços sociais, falando a "língua" dessas pessoas.

Arendt reconhece que, de fato, a propaganda exerce um papel crucial no totalitarismo, exercendo uma atração sobre a mentalidade da ralé. De acordo a autora, a característica principal deste tipo de propa- 
ganda é afastar-se enormemente de qualquer concepção razoável do que seja o bem ou a virtude, é uma propaganda centrada, pelo contrário, no mal e no crime, pois a ralé via os atos de violência como perversos, mas sinal de esperteza. A autora cita apenas a ralé neste ponto, mas é notório, e aqui podemos adicionar, que a propaganda totalitária era voltada também e principalmente para as massas. O ponto chave e o objetivo maior da propaganda é que, como explica Arendt, dentro da estrutura do totalitarismo, os membros fanatizados tornam-se inatingíveis por argumentos ou pela própria experiência. É um regime de identificação com o próprio regime, ou seja, de conformismo total.

O movimento nazista e os movimentos comunistas da Europa recrutaram os seus membros da massa, pessoas, como foi dito anteriormente, aparentemente indiferentes e apáticas, abandonadas pelos outros partidos por estes motivos, formando-se, deste modo, por uma maioria de pessoas que nunca haviam participado da política. Desta forma, foi possível a introdução de métodos inéditos de propaganda política, que atuaram em meio a uma indiferença aos argumentos da oposição. Tais movimentos totalitários, então, tiveram toda a possibilidade de moldar um grupo "isolado" dos partidos tradicionais. Assim, lidando com pessoas que hostilizavam igualmente todos os partidos, eles não precisavam refutar argumentos, e adotaram métodos que substituíam a persuasão pela morte e a convicção pelo terror.

Outro ponto de aparente semelhança entre a tirania e o totalitarismo é a presença do terror sobre a população. Contudo, o terror ditatorial difere do terror totalitário por ameaçar apenas adversários autênticos, e não cidadãos inofensivos e sem opiniões políticas, como acontece no totalitarismo. O terror a cidadãos inofensivos liga-se à necessidade do totalitarismo de atomizar toda a sociedade. As massas que já existiam são ampliadas pelo referido processo de atomização. Não basta a igualdade de condições para os governados, típica dos despotismos e das tiranias, mas o fim de todos os laços não-políticos entre os subjugados, como os laços de família e os interesses culturais comuns. O totalitarismo busca chegar ao ponto de extinguir "a existência autônoma de qualquer atividade que seja" (ARENDT, 1998, p. 372). O mecanismo de perseguição é o da culpa por associação, onde se é culpado por se ter simplesmente uma ligação de algum tipo com um outro indivíduo considerado culpado.

Arendt afirma que os movimentos totalitários são "organizações maciças de indivíduos atomizados e isolados. Distinguem-se dos outros partidos e movimentos pela exigência de lealdade total, irrestrita, incondicional e inalterável de cada membro individual" (ARENDT, 1998, p. 373). Essa lealdade total só pode existir em indivíduos completamente isolados, sem laços sociais, e que "só adquirem o sentido de terem lugar neste mundo quando participam de um movimento, pertencem ao partido" (ARENDT, 1998, p. 373). Para isso, a fidelidade não deve possuir um conteúdo concreto, definido, pois o conteúdo concreto dá espaço para mudanças de opinião. Os movimentos totalitários, logo, livraram-se de programas com conteúdo deste tipo. Não possuir sequer um objetivo político é, aliás, uma das principais características do totalitarismo. Os movimentos em questão, na verdade, segundo Arendt, não se contentaram com o simples objetivo de todo líder da ralé, que é apenas tomar o poder, governando, posteriormente, por meios externos, ou seja, pela imposição, mas "descobriu um meio de subjugar e aterrorizar os seres humanos internamente" (ARENDT, 1998, p. 375).

Segundo a autora, o terror, quando a oposição já foi suprimida, deixa de ser meio e passa a ser a essência do totalitarismo. O terror estabiliza os homens e libera as forças da natureza e da história. Os governantes são executores dessas leis históricas ou naturais. O fim não é o bem-estar dos homens, "mas a fabricação da humanidade, elimina os indivíduos pelo bem da espécie, sacrifica as 'partes' em benefício do 'todo" (ARENDT, 1998, p. 517). E esta "fabricação da humanidade” tem uma relação intrínseca, no pensamento de Arendt, com os campos de concentração, como veremos mais à frente. 


\section{A organização amorfa da ficção}

Arendt (1998) define a organização totalitária como a criação de uma grande ficção, visando dar às mentiras criadas, que giram em torno de uma ficção central, uma realidade operante, fazendo com que os membros ajam segundo um mundo fictício. Deste modo, organização não se separa da propaganda. $\mathrm{Na}$ fase anterior à tomada do poder, são criados movimentos de vanguarda, que diferem os membros do partido dos simpatizantes. As massas são divididas entre simpatizantes e membros. O número de simpatizantes é ampliado, enquanto o de membros é mantido dentro de limites. As organizações de vanguarda separam os membros do mundo exterior ao mesmo tempo em que são a ponte para este mundo. Nas palavras da filósofa, "a organização de vanguarda não apenas isola os membros, mas lhe empresta uma aparência de normalidade externa que amortece o impacto da verdadeira realidade de maneira mais eficaz que a simples doutrinação" (ARENDT, 1998, p. 432). Como os simpatizantes, inicialmente, não deixam de ser cidadãos inofensivos, é através deles que as mentiras dos movimentos totalitários ganham aceitação geral. As organizações de simpatizantes conferem ao movimento totalitário, divulgando as mentiras de forma mais suave e respeitável, uma aparência de normalidade, ao mesmo tempo em que toda a opinião pública termina repleta de elementos totalitários disfarçados de opiniões políticas normais. "As organizações de vanguarda funcionam nas duas direções: como fachada do movimento totalitário para o mundo não-totalitário, e como fachada deste mundo para a hierarquia interna do movimento" (ARENDT, 1998, p. 416). E esta relação se repete dentro do próprio movimento, em vários níveis, de forma que o membro do partido está separado dos simpatizantes, enquanto que a elite do movimento se separa dos membros comuns. O membro, ao contrário do mero indivíduo que adere a um partido, não possui profissão ou vida pessoal independente do próprio movimento. Os membros comuns representam o mundo exterior para os grupos militantes.

Essa estrutura neutraliza o dogma básico do totalitarismo de que o mundo se divide em dois lados inimigos entre si. Um dos lados é o movimento, o outro o resto do mundo, contra o qual o movimento deve lutar. Esse dogma gera a agressividade dos movimentos totalitários e o choque de tal dicotomia é neutralizado pela referida estrutura de graduação da militância, "na qual cada escalão reflete para o escalão imediatamente superior a imagem do mundo não-totalitário, porque é menos militante e os seus membros são menos organizados" (ARENDT, 1998, p. 433). É um tipo de organização na qual os membros não encaram diretamente o mundo exterior.

O ataque dos movimentos totalitários ao status quo se dá uma forma mais radical do aquele que se realiza pelos partidos revolucionários. Esse radicalismo é sustentado pela substituição que a organização proporciona à vida comum. O totalitarismo busca abolir a vida comum. Todas as relações sociais que substituem as normais, não-políticas, terminam acontecendo com grupos menos militantes. É um mundo organizado hierarquicamente, no qual as crenças totalitárias não se chocam contra o mundo "normal”, "os membros do partido são rodeados pelo mundo normal dos simpatizantes, e as formações de elite pelo mundo normal dos partidários comuns" (ARENDT, 1998, p. 417).

É um modelo que pode ser repetido indefinidamente, inserindo-se novas camadas. Arendt cita o exemplo do nazismo:

A SA, as tropas de assalto (fundada em 1922), foi a primeira formação nazista supostamente mais militante que o próprio partido; em 1926, foi fundada a SS como a formação de elite da SA; três anos depois, a SS foi separada da SA e colocada sob o comando de Himmler; Himmler levou apenas mais al- 
guns anos para repetir o mesmo jogo dentro da SS: um após outro - e cada qual mais militante que o grupo anterior - vieram à luz, primeiro, as tropas de Choque, depois as unidades da Caveira [...] (ARENDT, 1998, p. 418).

E, desta forma, Arendt cita uma sucessão de organizações (SS-Armada, Serviço de Segurança, Centro para Questões de Raça e Colonização) que formavam uma hierarquia cuja proximidade do topo aumentava o grau de radicalização.

É um tipo de hierarquia flutuante, segundo ela, muito conhecido em entidades secretas de controle ou serviços de espionagem, com a constante inserção de camadas que significam novos controles para controlar os controles já existentes. Essa hierarquia flutuante permite degradar, distanciar do centro do movimento, os escalões ou grupos que se mostrem diminuindo o radicalismo.

Segundo Arendt, as organizações fascistas com cor de camisa definida, não tinham o objetivo primordial de defesa ou agressão, mas da guerra ideológica contra o pacifismo que se alastrou pela Europa no pós-Primeira Guerra. A propaganda militarista era bem mais relevante do que o treinamento militar. Os grupos paramilitares uniformizados são chamados pela autora de "enfeites militares" (ARENDT, 1998, p. 420).

Para a autora, as formações de elite eram "núcleos mutáveis da militância", que devem ser entendidos junto com as outras organizações partidárias profissionais, que eram duplicatas paraprofissionais das já existentes. A intenção dos movimentos era dar a impressão de que todos os elementos da sociedade teriam representantes seus. Para Arendt, "o fim último da propaganda nazista era organizar todos os alemães como simpatizantes" (ARENDT, 1998, p. 421). Essas instituições tinham um valor profissional muito pequeno, assim como suas imitações do exército tinham muito pouco valor militar. Contudo, eles criavam um mundo de aparências.

A referida técnica de duplicação foi utilizada para solapar instituições já existentes. Também queriam estar prontos para seu maior objetivo: penetrar em todas as posições de poder. Qualquer grupo da sociedade não-totalitária é tratado como ameaça ao movimento. Quando os nazistas tomaram o poder, destruíram imediatamente as organizações de professores já existentes através de suas organizações de professores, e assim fizeram com todas as outras. Mudaram de repente não só a vida política, mas toda a estrutura da sociedade.

As organizações paramilitares eram organizadas com a mesma estrutura das gangues e tinham função oposta às organizações de vanguarda. Assim Arendt define:

enquanto as últimas emprestam ao movimento um ar de respeitabilidade e inspiram confiança, as primeiras, disseminando a cumplicidade, fazem com que cada membro do partido sinta que abandonou para sempre o mundo normal onde o assassinato é colocado fora da lei, e que será responsabilizado por todos os crimes da elite. Consegue-se isto no estágio anterior ao poder, quando a liderança sistematicamente assume responsabilidade por todos os crimes e não deixa dúvida de que foram cometidos para o bem final do movimento (ARENDT, 1998, p. 422).

O muro mais eficaz a separar o movimento do mundo real é a violência. O membro tinha mais medo de deixar o movimento do que ser punido por seus atos ilegais. Havia um sentimento de segurança dado pela violência organizada das organizações paramilitares, que protegiam os seus membros, de forma que a segurança andava lado a lado com o medo dessas próprias organizações.

A divisão operacional do movimento era assim constituída: formações de elite, membros e simpatizantes. Segundo Arendt: 
Uma das principais desvantagens do mundo exterior no trato com sistemas totalitários é que ele ignorava esse sistema e, portanto, confiava em que, por um lado, a própria enormidade das mentiras do totalitarismo o levaria à ruína e, por outro lado, seria possível aceitar a palavra do Líder e fazer com que ele a cumprisse, a despeito das suas intenções originais. Infelizmente, o sistema totalitário é imune a essas consequências normais; sua engenhosidade reside precisamente em eliminar a realidade que desmascara o mentiroso ou o força a legitimar as suas mentiras (ARENDT, 1998, p. 434).

Apesar de os membros não acreditarem naquilo que é dito ao público em geral, eles acreditam nos chavões ideológicos e na narrativa histórica que envolve o passado e o futuro, pois os movimentos totalitários tomaram os mesmos das ideologias do século XIX, transformando tudo isso, pela organização, em uma realidade operante. Essas mentiras ideológicas, como exigem uma crença absoluta para que o movimento possa operar, são cercadas por provas pseudocientíficas.

As formações de elite não precisam dessas "provas", não acreditam na literalidade dos chavões. Estes são para as massas, que possuem ainda muita ligação com o mundo normal. Tais formações têm uma educação para não distinguir verdade de mentira, realidade de ficção e transformar declaração de fato em declaração de finalidade. A mentalidade da elite foi forjada nas escolas de liderança totalitária. Sem essa mentalidade da elite, que não pensa no mundo como este de fato o é e não compara as mentiras com a realidade, o movimento não poderia partir para a realização da ficção. A virtude da elite é a lealdade ao líder.

A camada mais superior do sistema totalitário é o pequeno círculo que se estabelece em torno do líder. Esse círculo íntimo considera os chavões ideológicos como meros experientes com a finalidade de unir as massas, que podem ser alterados perfeitamente a depender do momento, desde que se mantenha o princípio organizador. Os mais altos escalões caracterizam-se por esta liberdade em relação à sua própria ideologia.

Segundo Arendt, o totalitarismo precisa evitar duas coisas: a sua "mumificação" em governo absoluto e a limitação de sua liberdade pelas suas próprias fronteiras. O absolutismo destruiria o ímpeto interno do movimento e o nacionalismo não permitiria a expansão externa, que era necessária à própria sobrevivência do movimento. É uma dupla pretensão: o domínio total e o governo mundial. É um estado de instabilidade permanente, uma coexistência entre governo e movimento. O líder precisa evitar que o mundo fictício adquira estabilidade, pois este acabaria com o próprio movimento e faria surgir um novo modo de vida, que encerraria a qualidade "total" do totalitarismo e jogaria o país na sujeição às leis das nações. A posse de todos os instrumentos de força e poder cria uma situação paradoxal, de jogar o totalitarismo no confronto com a realidade e da busca por evitar este confronto.

Canovan (2006) esclarece que tal política é vista por muitos teóricos como uma tentativa de construir uma utopia ou a perpetuação de uma situação de congelamento, que responderia às ansiedades da modernidade. Seria uma situação rígida, uniforme, como um lago congelado, o que é negado por Hannah Arendt, que enxerga o totalitarismo, pelo contrário, como um movimento de destruição caótico, nãoutilitário, dinâmico ao ponto da mania.

Em relação às leis, segundo Arendt (1998), o totalitarismo demonstra uma indiferença em relação a estas e um desrespeito com as suas próprias. As instituições não se definem pelas normas que as regem. É um estado de permanente ilegalidade em meio a uma afirmação de uma identidade entre lei e ética (tornando a regulamentação inútil). Nas palavras da autora, "o direito é aquilo que é bom para o movimento" (ARENDT, 1998, p. 461)

O Estado totalitário possui uma dupla autoridade (partido e Estado) e seu governo é "amorfo" 
(sistema como ausência de sistema). Há uma autoridade aparente e uma real, "muitos descrevem a máquina governamental do regime totalitário como fachada importante, a esconder e disfarçar o verdadeiro poder do partido" (ARENDT, 1998, p. 445). Além disso, todos os níveis da máquina administrativa totalitária possui uma duplicação de órgãos, duplicando todas as funções administrativas. Essa duplicação não explica o "amorfismo" da estrutura. O que acontece é que o movimento está sempre mudando o verdadeiro centro do poder, sem dissolver aqueles grupos onde a autoridade foi eliminada. A multiplicação de órgãos estava ligada à constante transferência do poder. Quanto mais visível era uma instituição, menos poder detinha. "O verdadeiro poder começa onde o segredo começa”" (ARENDT, 1998, p. 453).

O "amorfismo" do Estado totalitário era o instrumento ideal para o seu princípio da liderança. A sobreposição dos órgãos impede a sabotagem, pela simples possibilidade de mudança de ênfase. O princípio do líder não estabelece hierarquia nem no Estado nem no movimento. A autoridade não parte do topo e chega à camada mais baixa, como no autoritarismo. Para Arendt, "o princípio da autoridade é, para todos os efeitos, diametralmente oposto ao princípio do domínio totalitário” (ARENDT, 1998, p. 455). Este não visa simplesmente restringir a liberdade, visaria eliminar a liberdade e até a espontaneidade humana. Entre o líder e os governos não existem níveis intermediários de autoridade bem demarcada. O desejo do líder pode estar em qualquer lugar em qualquer momento. Este escolhe arbitrariamente que órgão vai executar suas ordens. Além disso, toda a autoridade dos governantes locais emanava diretamente do líder, de forma que este possui um monopólio do poder. Aliás, não se trata apenas de um monopólio do poder, mas da confusão da hierarquia, do amorfismo, o que dá uma independência completa ao líder em relação aos subordinados.

\section{0 verdadeiro executivo, a virtude no totalitarismo e os campos de concentração}

O verdadeiro poder executivo do regime totalitário é a polícia secreta. É através dessa que as ordens são transmitidas. Segundo Arendt, "através da rede de agentes secretos, o governante totalitário cria uma correia transmissora diretamente executiva que, em contraposição com as camadas superpostas da hierarquia ostensiva, é completamente separada e isolada de todas as outras instituições" (ARENDT, 1998, p. 480). De acordo com a autora, a classe verdadeiramente governante é o grupo de agentes da polícia secreta, cujas normas e valores permeiam toda a sociedade.

$\mathrm{Na}$ filosofia política antiga, a questão da virtude tinha um papel central na teoria das formas de governo, por ser aquilo que dirigia o governo ao bem comum, separando, portanto, as formas de governo boas das más. O totalitarismo, em seu estranho simulacro de boa monarquia, deu a sua versão do assunto, na forma de uma superioridade racial (no caso do nazismo).

Segundo Arendt, "Os nazistas não achavam que os alemães fossem uma raça superior, à qual pertenciam, mas sim que deviam ser comandados, como todas as outras nações, por uma raça superior que somente agora estava nascendo. A aurora dessa nova raça não eram os alemães, mas a SS" (ARENDT, 1998, p. 461-462). O império mundial "germânico" ou "ariano" viria dali a séculos, mas o movimento queria demonstrar que conseguia fazer uma nova raça através da eliminação das outras.

No nazismo, a elite (na reorganização da SS, arquitetada por Himmler) era selecionada segundo o "bom sangue", ou seja, podiam remontar à sua origem "ariana" ou tinham mais de um metro e setenta de

altura ou eram loiros de olhos azuis. A elite selecionada por uma "comissão racial" e colocada sob "leis especiais de casamento" tinham como outro extremo os campos de concentração.

Para Hannah Arendt (1998), os campos de concentração têm uma função crucial no totalitarismo. 
São, no fim das contas, simplesmente o espelho e a miniatura da sociedade almejada. Em Origens do Totalitarismo, os campos de concentração são descritos como o local de experimento do domínio total, com o objetivo de transformação do caráter dos homens. São laboratórios, para tentar reduzir todas as pessoas à mesma identidade de reações. O que se busca, pela doutrinação ideológica das formações de elite e o terror dos campos de concentração, é a fabricação de uma nova espécie humana "que se assemelhe a outras espécies animais, e cuja única 'liberdade' consista em 'preservar a espécie”'(ARENDT, 1998, p. 488). O campo de concentração é a aplicação prática da doutrina ideológica, não servia apenas para degradar e exterminar pessoas, mas para a experiência de transformação da personalidade, para eliminar a espontaneidade da conduta humana.

Segundo Arendt, a espontaneidade não pode ser eliminada em circunstâncias normais, apenas em um campo de concentração. Este é, portanto, "o modelo social perfeito para o domínio total em geral" (ARENDT, 1998, p. 489). O fato de o domínio total depender do fechamento para o mundo proporcionado pelo campo de concentração espelha o fato da estabilidade do regime totalitário depender do isolamento eficaz do seu mundo fictício. A partir disso, a autora afirma que "os campos são a verdadeira instituição central do poder organizacional totalitário” (ARENDT, 1998, p. 489). É ali que os homens são transformados em "animais que não se queixam" (ARENDT, 1998, p. 489).

Nas palavras da filósofa, "Os campos de concentração são a instituição que caracteriza mais especificamente o governo totalitário” (ARENDT, 1998, p. 491). Era nos campos de concentração que perfeitos membros da SS eram treinados. Para Arendt, "a sociedade dos que estão prestes a morrer, criada nos campos, é a única sociedade em que é possível dominar o homem completamente" (ARENDT, 1998, p. 507). Segundo a visão da autora, o "cão de Pavlov", o espécime humano reduzido às reações mais elementares, o feixe de reações que sempre pode ser liquidado e substituído por outros feixes de reações de comportamento exatamente igual, é o "cidadão" modelo do Estado totalitário; e esse cidadão não pode ser produzido de maneira perfeita a não ser nos campos de concentração (ARENDT, 1998, p. 507).

\section{Conclusão}

Para Hannah Arendt, o totalitarismo surge em um contexto de despolitização da sociedade moderna, no qual a grande maioria da população não participava da arena pública. Em seu livro Origens do Totalitarismo (1998), escrito na própria época de ascensão do referido regime, a filósofa concluiu que se tratava de uma nova forma de governo, fundada em duas novas camadas sociais, a ralé e as massas, que tinham exatamente a característica de estarem à parte do sistema representativo, que hoje conhecemos como democracia representativa.

A originalidade do livro em questão é indubitável, ainda mais quando levamos em consideração que a opinião geral da época interpretava o totalitarismo como uma antítese da democracia e que a primeira tentação é catalogar de pronto o totalitarismo como uma tirania. O trabalho de Arendt, portanto, concentrou-se em grande medida em fazer a distinção entre totalitarismo e tirania. Foi desta distinção que a autora alemã retirou o que seriam as principais características do novo regime.

O livro de Hannah Arendt, um caldeirão envolvendo história, sociologia, filosofia, descrição fenomenológica, etc., traz, de fato, grandes dificuldades interpretativas. A afirmação de Carlton Hayes, de que o totalitarismo era uma nova forma de governo, cujos líderes vinham da plebe e se sustentavam nas massas, parece-nos ser o ponto zero de onde tudo emerge. Tomando o pano de fundo da teoria das formas de governo, cuja formulação mais clássica é a de Aristóteles (2009), concluímos que o totalitarismo mostra-se 
como um simulacro de uma monarquia virtuosa.

Em Hannah Arendt, a principal característica desta nova forma de governo é exatamente o simulacro, a imagem de outra realidade. O totalitarismo cria um mundo imagético, do qual o domínio total depende. Como, após dois ou três séculos de sonhos democráticos, de defesa de um mundo de liberdade, igualdade e fraternidade, a humanidade embarcou em um trem fantasmagórico, viajando em direção à autodestruição? Podemos começar a responder através do surgimento de um grande número de pessoas que foram, por circunstâncias político-históricas, expulsas deste sonho.

Acreditamos que a forma de governo mista à qual chamamos "democracia moderna", encontrada, por exemplo, em Montesquieu (1979) e no Federalista (1973), já foi desenhada intencionalmente para deixar a maior camada da população, ou seja, o povo, à parte das tomadas de decisões políticas. Contudo, Arendt não toca neste ponto, limitando-se a constatar que o período entre os séculos XIX e XX criaram um "exército" de indivíduos excluídos da democracia e que a ascensão do totalitarismo rompeu a ilusão de que a maioria dos indivíduos participavam ativamente do intitulado processo democrático.

Para explicar essas camadas populacionais, Arendt faz uma alteração no conceito que era o mais difundido de povo, dentro da mais tradicional teoria das camadas sociais, que via a sociedade como dividida entre monarcas, aristocratas e o demos, a plebe. Para ela, o povo era composto por todas as classes sociais, seria formado por aquele conjunto de indivíduos que representados ou que buscam uma representação no parlamento da democracia representativa. A ralé, por sua vez, também composta por indivíduos de todas as classes, seria composta dos declassés, do "lixo humano", dos excluídos da sociedade burguesa. Já as massas são formadas por indivíduos atomizados, extremamente individualizados, que não se unem por interesses comuns, não se articulam por classes, são isolados e não possuem "relações sociais normais" (p. 367). Vindas da sociedade do Estado-nação, as massas eram compostas de indivíduos desamparados, "supérfluos", que aderiam facilmente a um nacionalismo violento.

Tendo surgido estes dois novos grupos, o contexto do surgimento do totalitarismo estava formado. Segundo Arendt, os líderes totalitários vêm da ralé e contam com o apoio das massas. É um regime das massas, que atomiza a sociedade e busca integrar os indivíduos no todo que ela cria, apagando a identidade dos indivíduos.

Os líderes surgem da ralé, o sistema criado apoia-se nas massas e passa a movê-las, comandá-las, e devorá-las. O totalitarismo, para Arendt, começa a se diferenciar de fato da tirania quando elimina toda a camada de opositores e continua exercendo o terror na sociedade. É um terror gratuito, perene, sofisticado, contra indivíduos inocentes. É um regime que só funciona em países de grande população, de grandes massas supérfluas, capaz de suportar uma perda populacional considerável que advém da supracitada eliminação.

O totalitarismo precisa ter um líder, mas o papel do líder no regime o diferencia da tirania. O tirano estabelece todo o sistema abaixo dela para se manter no poder, o líder totalitarista é parte da engrenagem, a ponto de Arendt afirmar que ele é insubstituível - do ponto de vista de que é preciso ter um líder, que representa o comando e é um instrumento de desresponsabilização de toda a sociedade - e, ao mesmo tempo, perfeitamente substituível - no sentido de que o "líder" é só mais uma parte da engrenagem, o que conta é a imagem.

A propaganda, na visão da filósofa alemã, ao contrário do que muitos estudiosos pensaram, não sustenta todo o aparato do totalitarismo, mas este não se separa da propaganda. É uma propaganda, ao mesmo tempo, franca e mentirosa, falando o "idioma" da ralé e das massas, visando a ignorância e a estupidez, desprezando os padrões morais comuns e centrando-se no crime e na violência. A propaganda tota- 
litária torna os membros fanatizados inatingíveis por argumentos e pela realidade.

Em relação à organização do regime totalitário, o pensamento de Arendt, a nosso ver, é extremamente certeiro a respeito do seu amorfismo. O totalitarismo passa a imagem de uma hierarquia, mas, diferentemente do autoritarismo, sua hierarquia é amorfa, podendo inserir novas camadas de poder a qualquer momento e em qualquer degrau e formando uma cadeia de instituições duplicadas, na qual os poderes são alternados e as ordens podem partir de qualquer ponto da estrutura. Cada camada da estrutura cria uma nova realidade para a camada inferior e vice-versa. Por isso o totalitarismo governa com a propaganda (ideologia) em uma mão e o terror na outra. Além disso, o verdadeiro executivo é a polícia secreta, totalmente isolada das outras instituições. O caráter amorfo também está presente nos seus planos de domínio mundial, através do qual o totalitarismo evita ser engessado em um simples absolutismo, o que permitiria a visão mais realista dos indivíduos da realidade e faria o sistema perder a sua característica de domínio total.

A última observação que temos a fazer sobre a descrição de Arendt do totalitarismo é que, para a filósofa, e essa é para nós a análise mais impressionante do livro, o campo de concentração é o espelho e a miniatura da sociedade total almejada. É um laboratório de uma verdadeira distopia, no qual há o treinamento das formações de elite e a criação da "sociedade perfeita" almejada, onde, isolados do mundo, os seres humanos são transformados no "cão de Pavlov", em uma nova espécie sem espontaneidade.

Canovan (2006) tem uma frase que bem explica a interpretação de Arendt do totalitarismo: "terror em uma mão, ideologia na outra" (p. 27; tradução nossa). "O 'terror total”, diz Canovan, "como praticado nos campos, afirma Arendt, é 'a essência do totalitarismo"' (p. 27; tradução nossa). Para Arendt, o terror total visaria transformar não somente o homem das massas, mas todos os homens no "cão de Pavlov", ou seja, em um animal sem espontaneidade, um morto-vivo. Nesse sentido, o totalitarismo é uma forma de governo viral, que domina a sociedade através de uma organização que se assemelha a um vírus mutante e transforma os indivíduos em zumbis.

Por fim, afirmamos, da nossa parte, que não estamos totalmente convencidos de que o totalitarismo seria de fato uma nova forma de governo, que não se enquadraria na categoria da tirania. Pelo contrário, todavia ainda muito provisoriamente, tendemos a enxergar o totalitarismo como uma tirania, mas uma tirania em um mundo já muito diferente da Grécia Antiga, uma tirania que conta com os poderes fornecidos por toda uma revolução tecnológica. Além disso, não nos convencemos da classificação realizada entre povo, ralé e massa, tendendo a enxergar o povo simplesmente como o povo, que, por sinal, foi excluído intencionalmente da participação política na forma de governo à qual denominamos "democracia moderna", deixando terreno para os "grandes líderes". Enxergamos as massas como um processo de alheamento e de massificação cultural do povo em escala mundial. A possibilidade do ressurgimento das tiranias, em suas diversas maneiras de se apresentar, é algo latente em nosso mundo e o século XX foi imensamente frutífero nesse assunto. Todavia, tais questões ainda nos demandam muitas pesquisas futuras e ficam, portanto, para trabalhos posteriores. O mais importante é que Origens do Totalitarismo (1998), escrito em meio a alguns dos acontecimentos mais sombrios da humanidade, traz uma riqueza de pensamento e questionamento que torna obrigatório que nos refiramos a este livro sempre que tratarmos desse assunto.

\section{Referências}

ARENDT, Hannah. (1949). Origens do Totalitarismo. Trad. Roberto Raposo. São Paulo: Companhia das Letras, 1998.

ARISTÓTELES. A Política. Bauru, SP: Edipro, 2009. 
. Ética a Nicômaco. Brasília: Editora da UNB, 1985.

BUCKLER, Steve. (2011). Hannah Arendt and the Political Tradition. Edinburgh: Edinburgh University Press, 2011.

CANOVAN, Margaret. (2006). "Arendt's theory of totalitarianism: a reassessment". In: The Cambridge Companion to Hannah Arendt. Cambridge: Cambridge University Press, 2006.

CORREIA, Adriano. (2006). “Vícios Privados, Prejuízos Públicos”. Philósophos, v. 11, n. 1, p. 15-30.

LOCKE, John. (1689). Segundo Tratado Sobre o Governo Civil. Petrópolis: Vozes, 2001.

HAMILTON, A. et al. (1788). O Federalista. São Paulo: Abril Cultural, 1973. Os Pensadores.

MONTESQUIEU. Do Espírito das Leis. (1748). São Paulo: Abril Cultural, 1979. Os Pensadores.

MORGENTHAU, Hans. (1997). "Arendt on Totalitarianism and Democracy". Social Research, v. 44, n. 1, p. 127-131.

PLATÃO. A República. São Paulo: Difusão Européia do Livro, 1965.

VILLA, Dana. (2006). “Introduction: the development of Arendt's political thought". In: The

Cambridge Companion to Hannah Arendt. Cambridge: Cambridge University Press, 2006.

WOLIN, Sheldon. (1983). "Hannah Arendt: Democracy and The Political”. Salgamundi, n. 60, p. 319.

Artigo recebido em: 23 de dezembro de 2019

Artigo aceito em: 28 de fevereiro de 2020 